\title{
Decreased depth penetration of Fucus vesiculosus (L.) since the 1940's indicates eutrophication of the Baltic Sea
}

\author{
Nils Kautsky ${ }^{1}$, Hans Kautsky ${ }^{1}$, Ulrik Kautsky ${ }^{1} \&$ Mats Waern ${ }^{2}$ \\ ${ }^{1}$ Askö laboratory, Institute of Marine Ecology and the Department of Zoology, University of Stockholm, S-106 91 Stockholm, \\ Sweden \\ ${ }^{2}$ Institute of Plant Ecology, University of Uppsala, Box 559, S-751 22 Uppsala, Sweden
}

\begin{abstract}
Although nutrient inputs to the Baltic Sea have increased drastically since the end of the last century, there is still little hard biological evidence of a general eutrophication of the Baltic Sea outside locally polluted areas. A revisit after $40 \mathrm{yr}$ to some well-documented diving stations in the outer archipelago of the Aland Sea gave us an opportunity to register any changes in benthic vegetation that could be linked to eutrophication. By mapping the vertical distribution in coverage of bladder wrack Fucus vesiculosus (L.) at 11 stations we observed that the lower limit of this alga had moved upwards at 10 stations from maximally $11.5 \mathrm{~m}$ in $1943 / 44$ to $8.5 \mathrm{~m}$ in 1984 . Also the depth of maximum development had withdrawn from 5 to $6 \mathrm{~m}$ in 1943/44 to 3 to $4 \mathrm{~m}$ in 1984, while coverage at these depths was about the same: $58 \%$ and $51 \%$ respectively. The deepest specimens today at $8.5 \mathrm{~m}$ had the same dwarfed appearance as those found at $11.5 \mathrm{~m}$ in the 1940's; at that time growth at $8.5 \mathrm{~m}$ was luxuriant. During both studies the decrease in $F$. vesiculosus coverage with depth towards the lower limit could be approximately fitted to an exponentially decreasing light attenuation curve. Since the structure of Baltic hardbottom communities is almost totally governed by abiotic factors, the changes in depth penetration are probably caused by decreased transparency of the water column due to eutrophication. Results indicate that the decreased water transparency arises from a 40 to $50 \%$ increase in summer values of chlorophyll $a$ and nutrients in the offshore surface water of the Baltic Sea since the 1940's.
\end{abstract}

\section{INTRODUCTION}

Man's activites have drastically increased nutrient inputs to the oceans, yet there are still very few indications of regional eutrophication (UNEP 1982). This is because most nutrients from land are generally efficiently trapped in the coastal zone where they may cause local eutrophication effects.

In the Baltic ecosystems, long-term changes are caused not only by climatological factors such as salinity and temperature (Fonselius et al. 1984), but also by anthropogenic impacts such as eutrophication (review in Melvasalo et al. 1981). Local eutrophication has been responsible for changes in benthic vegetation in many coastal areas of the Baltic Sea over the past century (review in Wallentinus 1981) and the possible eutrophication of the open Baltic Sea has recently been thoroughly reviewed by Larsson (1985). Increasing trends in nutrient levels of the Baltic have been regis- tered since measurements started in the late 1950's (Fonselius 1980, Nehring et al. 1984), and calculations of nutrient inputs indicate a 4 -fold increase in the nitrogen and an 8-fold increase in the phosphorus load since the end of the last century (Larsson et al. 1985). There is, however, still little hard biological evidence for eutrophication of the Baltic Sea outside locally polluted areas.

There is no direct evidence of increased pelagic primary production in the open Baltic because timeseries have been of too short a duration and also because different methods have been used (Nehring et al. 1984). Good 'historical' data are also lacking (Melvasalo et al. 1981). However, increased primary production is indicated, indirectly, by decreasing oxygen levels in deep waters since the beginning of this century (Fonselius 1969). Analysis of zinc contents in sediment cores may also indicate increased sedimentation of organic matter in the open Baltic Sea (northern 
Baltic proper, Gotland Deep and Bornholm Basin) at least since about 1935 (Hallberg 1974, Suess \& Erlenheuser 1975, Niemistö \& Tervu 1978).

Furthermore the doubling in Baltic fish catches, from 450000 tons $\mathrm{yr}^{-1}$ in the late 1950 's to about 900000 tons $\mathrm{yr}^{-1}$ from 1974 onwards (Mankowski 1978), may reflect increased primary productivity, although a simultaneous increase in fishing effort might also partly explain the higher yields (Thurow 1980, Nehring et al. 1984, Aneer 1985, Hansson 1985).

A severalfold increase since the 1920's in benthic fauna (mainly filter feeders) above the halocline in the NW Baltic proper was documented by Cederwall \& Elmgren (1980). They suggested their data indicated eutrophication resulting in increased food availability for the benthos. This interpretation was questioned by Persson (1981) who thought the increase more likely to be a result of decreased predation pressure on benthos due to presumed overfishing of demersal fish during the 1930 's.

With the exception of the well-documented diving investigations by Waern in the Åland Sea during 1943/ 44 (Waern 1952), no quantitative samples from rocky benthic communities in the Baltic Sea exist before the end of the 1960's. A revisit to these early stations gave us an unique opportunity to determine whether there had been any major changes in benthic communities in this area in the intervening period. In this paper we discuss changes observed in the depth distribution of bladder wrack Fucus vesiculosus, and argue that these data can be used as a biological indicator of long-term changes in abiotic factors.

\section{MATERIAL AND METHODS}

Study area. A general description of the morphology and hydrology of the investigation area along with vegetation zonation and biomass distribution is given by Waern (1952). Due to the low salinities in the Baltic, Fucus vesiculosus is a very important component of the ecosystem. It is the only large, belt-forming brown alga found in the northern Baltic proper and the Aland Sea. In tidal marine environments outside the Baltic, $F$. vesiculosus is restricted to the upper part of the intertidal belt. In the practically tideless Baltic, however, it can be found as a continuous belt from just below the extreme low water level down to $10 \mathrm{~m}$ depth and more in clear waters (Levring 1940, Waern 1952, 1965, Kautsky 1984). In the archipelagos of the northern Baltic proper maximum cover and biomass are generally found between 0.5 and $5 \mathrm{~m}$ depth (Jansson \& Kautsky 1977).

In the investigated area, the southeastern part of the Oregrund Archipelago, Fucus vesiculosus has a wide distribution on rocky bottoms, from rather sheltered bays to exposed skerries (Waern 1952). Except for the innermost sheltered areas the algal biomasses are totally dominated by $F$. vesiculosus.

Eleven of the stations investigated during 1943/44 (Waern 1952) were revisited in June 1984 (Fig. 1).

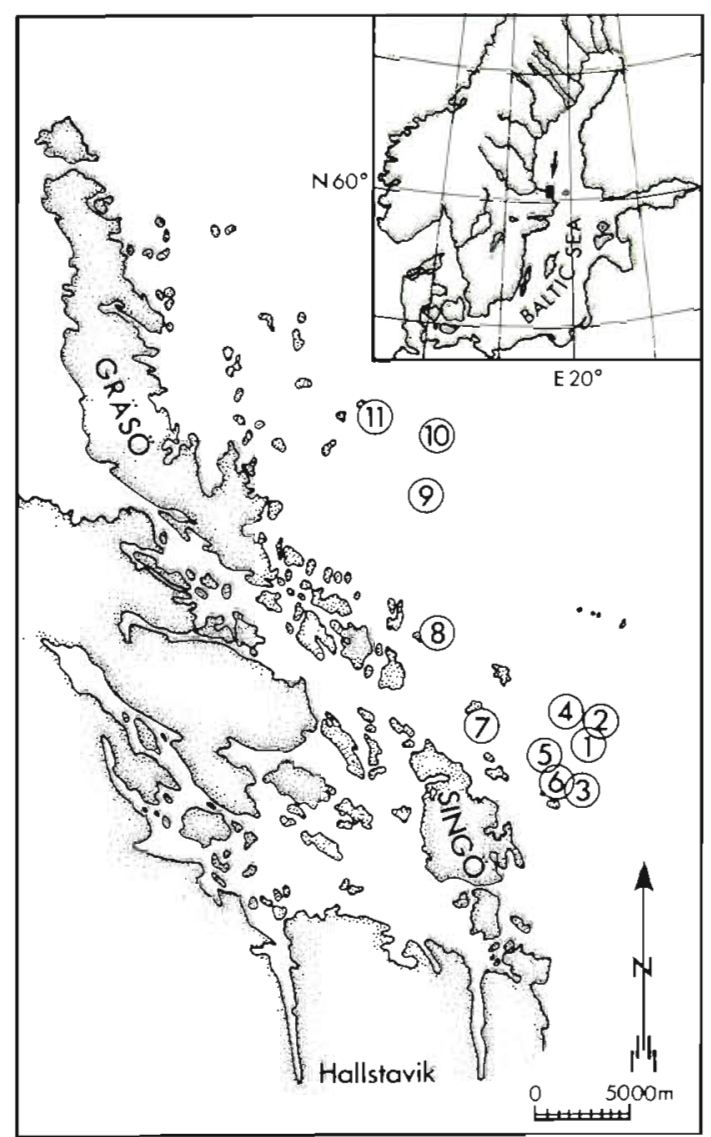

Fig. 1 Investigation area with positions of revisited diving transects

These stations are mainly situated in the outer part of the archipelago facing the $\AA$ land Sea. There is a large water exchange through this area with dominating surface-water currents (up to $1 \mathrm{~m} \mathrm{~s}^{-1}$ ) coming from the north (Ambjörn et al. 1983), which indicates that the investigation area is well ventilated.

The western and northernmost stations of Waern were not revisited since this part is influenced by water from the River Dalälven (Waern 1952). Nor were some of the innermost stations investigated since they were not deep enough to include the lower part of the vegetation-covered bottoms; also they may be influenced by local municipal discharges of the pulp mill effluents from Hallstavik, where local changes in the soft bottom fauna have been observed inside the island of Singö (H. Cederwall pers, comm.). 
Methods. Diving transects were placed as close as possible to the diving sites of Waern in 1943/44. To relocate the original spots we used the marked navigation charts used by him together with his land and underwater photographs and original transect drawings. These were complemented with echo soundings and with verbal instructions from Waern himself in the field.

Since Waern (1952) used helmet diving, he was connected to the boat by an air-supply line. Although the boat could be towed between 2 anchor points, Waern's operational range was limited compared to that of the SCUBA divers. All Waern's observations were transmitted by telephone to the boat where they were written down. Depth was hand-sounded during the 1943/44 study, while calibrated depth gauges (SOS Helium, Italy) were used in 1984. A comparison of the 2 methods, by using easily identified structures on the bottom and correcting for water-level variations, gave slightly deeper values for the hand-soundings. This is largely explained by the land-rise in this area of Sweden amounting to $0.0061 \mathrm{~m} \mathrm{yr}^{-1}$ (Anon 1975) i.e. about $0.25 \mathrm{~m}$ for the past $40 \mathrm{yr}$. Since all depth values are related to actual mean water levels during the years studied, this land-rise will not influence later discussions on changes in the depth distribution of Fucus vesiculosus.

The sampling methods used in the present investigation were described in earlier papers (Jansson \& Kautsky 1977, Kautsky et al. 1981) and essentially follow the recommendations of the Baltic Marine Biologists (Dybern et al. 1976). The variation with depth in the degree of cover of major plant and animal species was noted along a line marked at meter intervals placed on the bottom. Special care was taken to register the deepest finds of Fucus vesiculosus. At Station 10 in 1984 and at Station 6 in 1943/44 this was the only work undertaken.

Slightly different methods for estimating the degree of plant cover were used in the 2 studies. In 1943/44 the relative 5-point scale of Hult-Sernander-Du Rietz (Waern 1952 p. 230) was used within deployed quadrats measuring $0.25 \times 0.25 \mathrm{~m}$. The cover classes used and a translation of these values to percentage cover is given in Table 1. Waern sometimes also used a kind of general covering degree within his field of vision (2 to

Table 1. Translation of cover estimates used in 1943/44 to percentage used in present calculations

\begin{tabular}{|ccc|}
\hline \multicolumn{2}{|c|}{$\begin{array}{c}\text { Estimates used 1943/44 } \\
\text { Astimate }\end{array}$} & $\begin{array}{c}\text { Translation } \\
\text { to } \%\end{array}$ \\
\hline 5 & $1 / 1-1 / 2$ & 75.0 \\
4 & $1 / 2-1 / 4$ & 37.5 \\
3 & $1 / 4-1 / 8$ & 17.5 \\
2 & $1 / 8-1 / 16$ & 7.5 \\
1 & $<1 / 16$ & 2.5 \\
\hline
\end{tabular}

$8 \mathrm{~m})$. In 1984 a 7 -point scale $(1,5,10,25,50,75,100 \%)$ of the percentage of bottom area covered by the different species within 3 to $5 \mathrm{~m}$ on each side of the transect line was used.

\section{RESULTS}

In 1943/44 Fucus vesiculosus was found down to 11.5 $m$ depth at 2 stations. In 1984, the deepest findings had risen by $3 \mathrm{~m}$ to $8.5 \mathrm{~m}$ depth (Table 2). At 8 out of 11 stations the deepest finds of $F$. vesiculosus in $1943 / 44$

Table 2. Fucus vesiculosus. Lower depth limits at different stations in 1943/44 (Waern 1952) compared with 1984 (present investigation). ve $=$ very exposed, $\mathrm{e}=$ exposed to waves

\begin{tabular}{|c|c|c|c|c|c|c|c|}
\hline & \multirow[t]{2}{*}{ Station no. } & \multicolumn{2}{|c|}{$\begin{array}{c}\text { Direction and exposure } \\
\text { of transect }\end{array}$} & \multicolumn{2}{|c|}{$\begin{array}{l}\text { Maximum depth } \\
\text { of } F \text {. vesicolosus }\end{array}$} & \multirow[t]{2}{*}{ Difference } & \multirow[t]{2}{*}{ Comment } \\
\hline & & & & $1943 / 44$ & 1984 & & \\
\hline & 1 & $\mathrm{~S}$ & ve & $\geq 9.5$ & 7.5 & $(-2.0)$ & (1) \\
\hline & 2 & $N$ & ve & 10.0 & 7.5 & -2.5 & \\
\hline & 3 & $\mathrm{SE}$ & ve & 11.5 & 7.8 & -3.7 & \\
\hline & 4 & W & e & 10.5 & 8.5 & -2.0 & \\
\hline & 5 & $\mathrm{~N}$ & e & 8.8 & 6.5 & -2.3 & \\
\hline & 6 & $\mathrm{~S}$ & $\mathrm{e}$ & $\geq 8.0$ & 7.0 & $(-1.0)$ & (1) \\
\hline & 7 & $S$ & e & 11.5 & 7.8 & -3.7 & \\
\hline & 8 & $\mathrm{E}$ & $\mathrm{e}$ & 10.2 & 7.5 & -2.7 & \\
\hline & 9 & $\mathrm{~S}$ & $\mathrm{e}$ & 10.0 & 8.1 & -1.9 & \\
\hline & 10 & $\mathrm{~N}$ & $\mathrm{e}$ & $\geq 9.0$ & 8.0 & $(-1.0)$ & (2) \\
\hline & 11 & $\mathrm{SE}$ & e & $\geq 6.0$ & 7.0 & $(+1.0)$ & (1) \\
\hline $\begin{array}{ll}\text { (1) } & 1 \\
\text { (2) } & 1\end{array}$ & $\begin{array}{l}\text { Diving transe } \\
\text { Maximum de }\end{array}$ & $\begin{array}{l}\text { ese sit } \\
14 \mathrm{recc}\end{array}$ & may & reached & ower & of distribut & \\
\hline
\end{tabular}


were below the maximum of $8.5 \mathrm{~m}$ in 1984 . In 1943/44, diving was terminated at the remaining stations $(6,10$ and 11) before the maximum depth of $F$. vesiculosus had been determined. Thus at Stations 6 and 10 the registered withdrawal was only $1 \mathrm{~m}$. At Station 11 the 1984 investigation even found $F$ vesiculosus at $7 \mathrm{~m}$ depth, 1 m deeper than Waern did in 1943/44. Waern (1952; p. 276), however, writes about this station that 'the growth seems poor even below $6 \mathrm{~m}$ ' indicating that $F$. vesiculosus occurred also at greater depth.

The average changes in Fucus vesiculosus coverage between $1943 / 44$ and 1984 are shown in Fig. 2. While

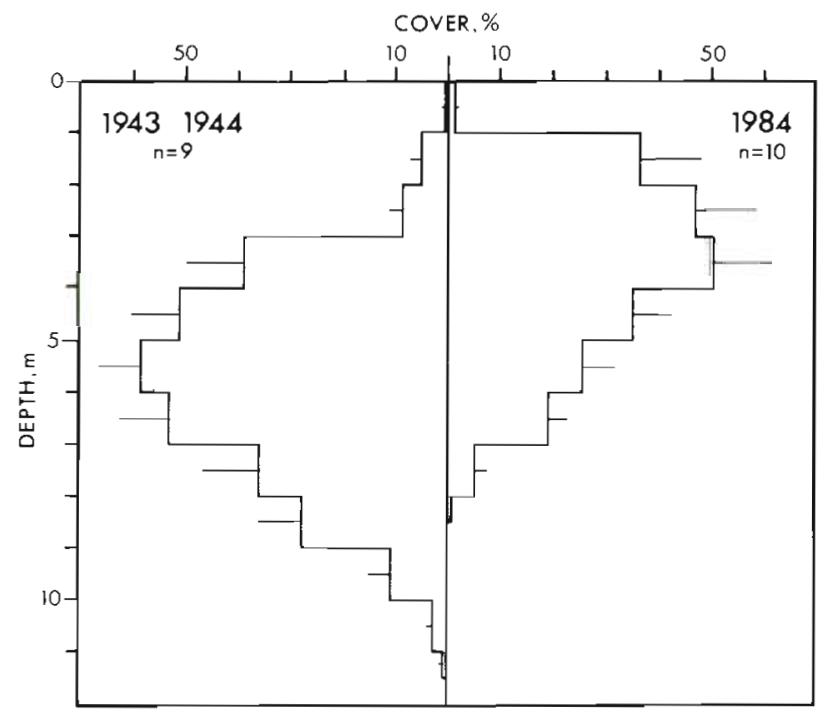

Fig. 2. Fucus vesiculosus. Percentage of bottom area covered in different depth intervals $\pm \mathrm{SE}$ of means, compared between 1943/44 and 1984. Station 6 in 1943/44 is excluded since it had no recorded cover estimates

the average maximum coverage has changed insignificantly from 58 to $51 \%$ over the period, it has shifted considerably in depth. In 1943/44, it was found at 5 to 6 $\mathrm{m}$ whereas the maximum in 1984 was in the 3 to $4 \mathrm{~m}$ depth interval. While a dense $F$. vesiculosus belt started at as little as $1 \mathrm{~m}$ depth in 1984, it did not begin until $3 \mathrm{~m}$ depth in 1943/44.

At all stations the pattern of changes between the 2 studies was the same, and no significant differences could be found between stations in different parts of the area or at stations with different exposure.

In Fig 3 the logarithmic value of $\%$ cover derived from Fig. 2 has been plotted against depth for the 2 investigations. For the deeper part of the graph, the points fall on straight converging lines, close to those expected had the changes in depth distribution of Fucus vesiculosus been directly related to changes in light attenuation due to decreased transparency of the water. Above about $25 \%$ coverage the curves bend. Possible explanations for the bend could be that at this

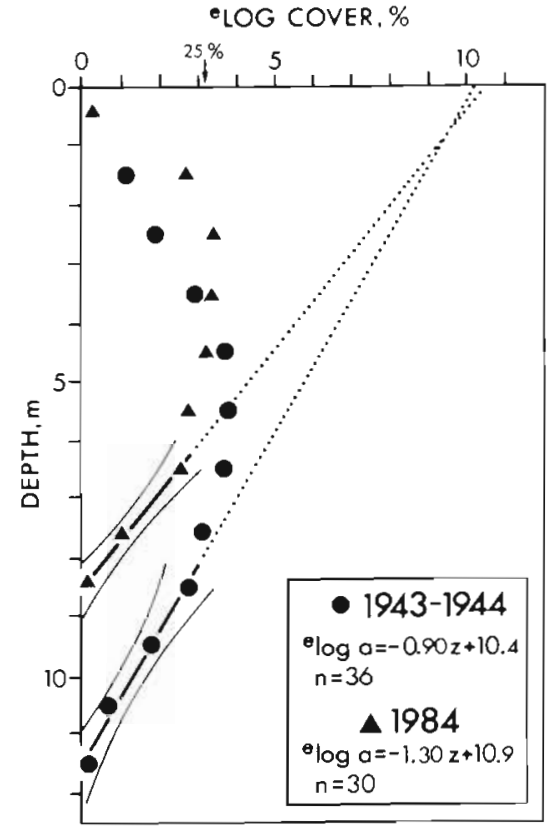

Fig. 3. Fucus vesiculosus. ${ }^{\mathrm{e}} \log \%$ average cover plotted against depth for the 2 investigations (cf. Fig. 2). The deeper observations have been fitted to straight lines. Each point represents the weighted mean of all values within the depth interval. $95 \%$ confidence limits are given. Above about $25 \%$

cover the points no longer fall on the lines (see text)

cover density, growth of $F$. vesiculosus becomes limited by shading from other fronds, by whiplash effects, or by other types of intraspecific competition. Shading from epiphytes will also generally increase at shallower depths. Above 3.5 and $5.5 \mathrm{~m}$ depth in 1984 and $1943 / 44$, respectively, the disturbance of the communities by ice erosion and strong wave action can also be seen.

\section{DISCUSSION}

In locally polluted areas eutrophication is generally accompanied by decreased depth extension of benthic vegetation due to increasing turbidity (Pekkari 1973, Lindgren 1975). In general, there will also be a shift in dominance towards opportunistic bluegreen, green and brown algae (Wallentinus 1981). These may grow as epiphytes on perennial species such as Fucus vesiculosus or certain red algae, which are then sometimes out-competed through shading or nutrient depletion (Kangas et al. 1982, Wallentinus 1984a, b, Wallentinus et al. 1985).

The recession of algal vegetation due to decreased light transmission in the Baltic is often followed by an invasion of carpets of filter-feeding blue mussels (Waern 1965, Luther 1972, Mathiesen 1974, Wallentinus 1979). The mussels may start to dominate from as little as 1 to $2 \mathrm{~m}$ depth in eutrophied sewage receivers 
owing to increasing amounts of food and reduced competition for space by the algae (N. Kautsky unpubl.).

Fluctuations in species composition on true marine rocky bottoms are generally due to species interaction through predation, herbivory, competition etc. or disturbance due to changes in physical factors (Dayton 1971, Connell 1972, Menge 1976, Paine 1977). This multitude of causes and the resulting long and short term cycling makes it difficult to evaluate the effects of biological and abiotic factors in monitoring programmes (cf. Lewis 1976).

On the other hand, the Baltic ecosystems are comparatively stable with regard to species structure since major herbivores on macroalgae (e.g. sea urchins, Littorina spp., Patella spp.) and major predators on Mytilus edulis (e.g. Asterias spp., Carcinus spp.) are lacking, and because there is less interspecific competition due to the lower number of species present (Kautsky 1981). Observed changes in coverage or species composition are thus likely to reflect changes in environmental factors in the same way as the seasonal variation in light and nutrients are mirrored by the well-known blooms of phytoplankton or annual filamentous algae such as Pilayella littoralis.

Fucus vesiculosus has a lifespan ranging from 4 to 5 yr (Kangas et al. 1982) and up to extremes of 9 to $10 \mathrm{yr}$ as observed in the sheltered part of the present investigation area, while Mytilus edulis may live to an age of 20 yr (Kautsky 1982). We believe that changes in the coverage of such long-lived species can be used to monitor long-term changes in environmental factors in the Baltic, generally with a higher resolution and efficiency than, for example, monthly measurements of nutrients and water transparency.

In marine environments the upper limit of intertidal sessile plants and animals are generally believed to be set by physical factors. This has never been conclusively shown for the lower limits of algae, which are believed rather to be determined mainly by biological interactions (reviews in Hawkins \& Hartnoll 1983 and Underwood \& Denley 1984).

In the Baltic Sea the upper limit of Fucus vesiculosus is determined by physical stress due to desiccation at low water, wave action and/or ice abrasion. Drifting pack-ice is said to be capable of scouring to at least $5 \mathrm{~m}$ depth (Waern 1952 p. 19). The observed lower coverage of $F$. vesiculosus above $3 \mathrm{~m}$ depth in the 1943/44 material is thus probably explained by the 3 ice winters in $1939 / 40$ to $1941 / 42$, the most severe of the century (Anon 1983). In contrast, the winters prior to the 1984 study were fairly normal (Anon 1983), which is reflected in denser growth closer to the water surface. However, there are some other factors which may cause changes in the same direction. In areas where $F$. vesiculosus becomes limited by salinity it has been noted that the upper boundary of the $F$. vesiculosus belt moves deeper. Thus, even today, F. vesiculosus is not found above about $3 \mathrm{~m}$ depth inside the island of Gräsö. In low salinity areas that are enriched by nutrients, such as close to sewage outlets or around skerries fertilized by bird droppings etc. F. vesiculosus may grow close to the surface again (Waern 1952, Pekkari 1973). The increase in both salinity and nutrient levels since the 1940's will thus have stimulated an upward extension of $F$. vesiculosus towards the surface.

The lower physiological depth limit of algal growth is determined by light availability which is limited by water transparency or sediment 'dust' on the algae or on the bottom. In the Aland Sea, with few biological interactions, this will most probably be the depth limit also for single algal species like Fucus vesiculosus. This means that the observed decrease in maximum depth from $11.5 \mathrm{~m}$ in $1943 / 44$ to $8.5 \mathrm{~m}$ in 1984 is likely to be directly related to a corresponding decrease in light.

No physical factor other than light is likely to have caused the observed effect. Since the bottoms are continously swept clean in this open archipelago an increased sedimentation rate would not increase the amount of detritus on the bottoms and lead to suffocation' of the vegetation. Theoretically, any change in a factor that lowers the 'scope for growth' of Fucus vesiculosus e.g. by increasing its respiration, will tend to decrease the maximum depth of penetration of $F$. vesiculosus. The direct effects of the registered increased in temperature since the $1940^{\circ} \mathrm{s}$ of about $0.5 \mathrm{C}^{\circ}$ and in salinity of about $0.5 \%$ (Melvasalo et al. 1981) on the physiology of $F$. vesiculosus must, however, be regarded as insignificant in influencing its lower limit (cf. Bird et al. 1979, Fortes \& Lüning 1980). Also, the registered increases in heavy metals, chlorinated hydrocarbons, oil etc. since the 1940's (Melvasalo et al. 1981) are so low that they cannot account for the observed changes in depth distribution of $F$. vesiculosus.

Indirectly the salinity increase could improve conditions for some marine species which were earlier living at their tolerance limits, and thus increase competition for space. There were, however, no signs of severe algal competition for space at the lower limit of Fucus vesiculosus and although Mytilus edulis seems to have increased since the 1940's, there were bare, uncovered rock surfaces present at the time of revisiting, which was also a likely time for the settling of $F$. vesiculosus spores.

The recent decline of Fucus vesiculosus reported from several other parts of the Baltic Sea, especially in Finnish coastal areas (e.g. Kangas et al. 1982, Hällfors et al. 1984, Mäkinen et al. 1984, Rönnberg 1984) is probably caused by several factors. In the most affected 
areas, there has been a more or less total decline of $F$. vesiculosus. Since most of the Finnish areas where Fucus vesiculosus disappeared are situated close to known upwelling areas of nutrient-rich bottom water, the disappearance is generally indirectly linked to eutrophication. Excessive growth of Pilayella Iittoralis is said to have directly outcompeted $F$. vesiculosus or favoured the reproduction of the isopods Idothea spp. which has led to overgrazing (e.g. Kangas et al. 1982 , Haahtela 1984, Hällfors et al. 1984). Grazing by Idothea spp. would, however, leave characteristic bite marks on the remaining $F$, vesiculosus which were not observed in the present study. Furthermore, the present investigation area was not noted as an upwelling area by Gidhagen (1984), and unlike Finnish areas, there has been no change in the coverage of $F$. vesiculosus at optimum depths.

Since the observed decline in coverage with depth in the deeper parts both today and during the 1940's follow patterns that can be expected from changes in the light attenuation curve, the most probable cause for the decreased depth extension of Fucus vesiculosus in the present investigation area is a general reduction in the light transmission of the water. This is also supported by the observation that the deepest plants today at $8.5 \mathrm{~m}$ were of the same dwarfed appearance as those found at $11.5 \mathrm{~m}$ in $1943 / 44$, while at that time growth at $8.5 \mathrm{~m}$ was rather luxuriant.

Thus we concluded that the likely cause is a decrease in water transparency, i.e. an increase in the light extinction rate. Waern (1952 p. 19) mentions that Secchi disc readings among the skerries were about 8 $m$ in the 1940's. During May to September in 1979 to 1982 this had decreased to an average of $6.9 \mathrm{~m}(\mathrm{n}=21$, $\mathrm{SE}=0.3$ ) at a monitoring station outside the island of Singö (E. Bergstrand, pers. comm.). Although this decrease supports our hypothesis, the observations from the 1940's are too few to conclude that these differences are significant. Furthermore, it does not give us any information as to what has caused the change in light transmission.

According to Hutchinson (1957), the total extinction rate is the sum of the extinction for pure water, dissolved substances, particles, and chlorophyll. The extinction for pure water will not have changed since the 1940 's. Dissolved substances comprise humic substances ('gelbstoff') and lignin sulfonates. No measurements of these are available from the 1940's. The observed salinity increase since then amounting to $0.5 \%$ would, however, lead to a reduction of both substances by about $10 \%$ due to precipitation (Nyquist 1979 , p. 186). Lignin sulfonates in the Baltic have probably also decreased since the 1940 's owing to successive closing down of most sulfite pulp mills, including that in Hallstavik. During 1974 to 1977 levels of about $1.5 \mathrm{mg} \mathrm{l}^{-1}$ of lignin sulfonates were measured in the southern Bothnian Sea (Nyquist 1979). Although probably higher than today's values, these levels would influence the photosynthetically active radiation only marginally (cf. Nyquist 1979, p. 132). Furthermore, Fucus vesiculosus, like other Phaeophyta, is less dependent on the spectral composition of the radiant energy than other algal groups because of its additional brown pigments (Levring 1967).

With regard to particulate matter, information is also very sparse and the data available (e.g. Jerlov 1975). do not allow any conclusions to be drawn. In any case, changes in particles would most likely be directly related to changes in phytoplankton biomass. Thus the large changes in the light climate accounted for by the increased extinction rate, and the change in depth distribution of Fucus vesiculosus appear to have been caused by an increase in chlorophyll.

By comparing the slopes of the regressions in Fig. 3 we can calculate that the average extinction rate has increased by $44 \%$ since the 1940 's, probably mostly due to increased chlorophyll levels. This would represent an integrated value for changes in the light climate during the annual growth season of Fucus vesiculosus, which is from May to September (Guterstam 1979), roughly coinciding with the period when a summer thermocline persists. Since the summer concentration of chlorophyll a is roughly proportional to the total summer nutrient concentration (e.g. Smith 1982), this would probably mean that total nutrients have also increased by a similar magnitude. The largest increases in chlorophyll following an enhanced nutrient load will, however, probably have taken place just outside this period, i.e. during the spring and autumn phytoplankton blooms, when production is not limited by stratification of the water column (cf. Larsson \& Hagström 1982).

Compared with the total input figures to the Baltic given by Larsson et al. (1985), indicating an 8-fold increase in nitrogen and a 4 -fold increase of the phosphorus load, the observed effect seems reasonable if we assume that most nutrients are bound up in the coastal effluent areas and that large amounts settle out of the photic zone. Sedimentation is high in the Baltic especially just at the end of the spring bloom, when about half the spring production has been found to settle to the bottom (Smetacek et al. 1980).

As the upward movement of the lower Fucus vesiculosus limit was of the same magnitude at all stations and since we could find no gradient in the results over the investigation area, which is well ventilated, we believe that the observed change is not due to any local effluents, but is representative at least of changes in the Aland Sea. 
We also suspect that a similar upward movement in the depth distribution of Fucus vesiculosus may have taken place in all parts of the Baltic parallel to the observed general increase in nutrient levels.

Acknowledgements. Many thanks are due to Per Jansson who acted as skipper during the field study and to the owners of 'Sunbeam' whose ship we used as floating laboratory and base. Dr Ragnar Elmgren, Professor Inger Wallentinus, Dr. Fredrik Wulff and 2 anonymous reviewers made valuable comments on the manuscript which was typed and corrected by Maureen Mour. The figures were drawn by Bibbi Mayrhofer Financial support was granted by the National Swedish Environmental Protection Board, project nos. 5312054-9 and 5312055-6 and by Helge Ax:son Johnssons stiftelse

\section{LITERATURE CITED}

Ambjörn, C., Broman, B., Peterson, C. (1983). Bottniska viken - vattenutbytesprocesser In: Cederwall, H. (ed.) Second Swedish-Finnish Seminar on the Gulf of Bothnia, National Swedish Environmenal Protection Board (SNV), Solna, pm 1618 , p. 22-26

Aneer, G. (1985). Some speculations about the Baltic herring (Clupea harengus membras) in connection with the eutrophication of the Baltic Sea. Can. J. Fish. Aquat. Sci. 42 (1): $83-90$

Anon. (1975). Vattenståndet vid Svenska kuster år 1975. Swedish Meteorological and Hydrological Institute (SMHI) Norrköping, Yearbook 57 (3): 2

Anon. (1983). Sammanfattning av isvintern 1982/83. A summary of the ice season 1982/83. SMHI, Yearbook 65 (2): 5

Bird, N. L., Chen, C.-M., McLachlan, J. (1979). Effects of temperature, light and salinity on growth in culture of Chondrus crispus, Furcellaria lumbricalis, Gracilaria tikvahiae (Gigartinales, Rhodophyta), and Fucus serratus (Fucales, Phaeophyta). Botanica mar. 22: 521-527

Cederwall, H., Elmgren, R. (1980). Biomass increase of benthic macrofauna demonstrates eutrophication of the Baltic Sea. Ophelia, Suppl. 1: 287-304

Connell, J. H. (1972). Community interactions of marine rocky intertidal shores. A. Rev. Ecol. Syst. 3: 169-192

Dayton, P. K. (1971). Competition, disturbance and community organization: the provision and subsequent utilization of space in a rocky intertidal community. Ecol. Monogr. 41: 351-389

Dybern, B. I., Ackefors, H., Elmgren, R. (ed.) (1976). Recommendations on methods for marine biological studies in the Baltic Sea. Baltic marine biologists (BMB) No. 1, p. $1-98$

Fonselius, S. H. (1969). Hydrography of the Baltic deep basins III. Fish. Board of Swed. Ser. Hydrogr. Rep. 23: 1-97

Fonselius, S. H. (1980). On long time variations of phosphorus in Baltic surface water. Coun. Meet. int, Coun. Explor. Sea C.M. ICES/C: 36 (Hydrography Committee)

Fonselius, S. H., Szaron, J., Óström, B. (1984). Long-term salinity variations in the Baltic Sea deep water. Rapp. P.-v. Réun. Cons. int. Explor. Mer. 185: 140-149

Fortes, M. D., Lüning, K. (1980). Growth rates of North Sea macroalgae in relation to temperature, irradiance and photoperiod. Helgoländer Meeresunters. 34: 15-29

Gidhagen, L. (1984). Coastal upwelling in the Baltic. Swedish Meterological and Hydrological Institute (SMHI), Reports Hydrology and Oceanography, Norrköping, Sweden, RHO 37, p. $1-37$ + appendix
Guterstam, B. (1979). In situ Untersuchungen über Sauerstoffumsatz und Energiefluß in Fucus-Gemeinschaften der Ostsee. Dissertation, Univ. Kiel

Haahtela, I. (1984). A hypotheses of the decline of the bladder wrack (Fucus vesiculosus L.) in SW Finland in 1975-1981. Limnologica (Berlin) 15 (2): 345-350

Hallberg, R. O. (1974). Paleoredox conditions in the eastern Gotland Basin during the recent centuries. Merentutkimuslait. Julk/Havsforskningsinst. Skr. 238: 3-16

Hansson, S. (1985). Effects of eutrophication on fish communities, with special reference to the Baltic - A literature review. Rep. Inst. Freshwat. Res. Drottningholm (in press)

Hawkins, S. J., Hartnoll, R. G. (1983). Grazing of intertidal algae by marine invertebrates. Oceanogr. mar. Biol. Rev. 21: $195-282$

Hutchinson, G. E. (1957). A treatise on Limnology Vol. 1. Geography, physics, and chemistry. Wiley, New York

Hällfors, G., Kangas, P., Niemi, $\AA$. (1984). Changes in the phytal at the south coast of Finland. Ophelia, Suppl. 3: $51-59$

Jansson, A.-M., Kautsky, N. (1977). Quantitative survey of hard bottom communities in a Baltic archipelago. In: Keegan, B. F., O'Ceidigh, P., Boaden, P. J. S. (ed.) Biology of benthic organisms. Pergamon Press, New York, p. 359-366

Jerlov, N. G. (1975), Long period changes of the optical properties of the Baltic. J. Cons. int. Explor. Mer, 36 (2): 188-190

Kangas, S. D., Autio, G., Hällfors, G., Luther, H., Niemi, $\AA$, Salemaa, H. (1982). A general model of the decline of Fucus vesiculosus at Tvärminne, south coast of Finland in 1977-81. Acta bot. fenn. 118, p. 1-27

Kautsky, H. (1984). Inventering av de grunda, vegetationstäckta bottnarna inom det planerade marina natureservatet Salvorev, Sandö bank och Kopparstenarna, maj-juni 1983. Report, Askö lab. Univ. Stockholm. p. 1-65 (Mimeo)

Kautsky, H., Widbom, B., Wulff, F. (1981). Vegetation, macrofauna and benthic meiofauna in the phytal zone of the archipelago of Luleå-Bothnian Bay. Ophelia 20 (1): 53-77

Kautsky, N. (1981). On the role of the blue mussel (Mytilus edulis L.) in a Baltic coastal ecosystem and the fate of the organic matter producted by the mussels. Kieler Meeresforsch. (Sonderh.) 5: 454-461

Kautsky, N. (1982). Growth and size structure in a Baltic Mytilus edulis population. Mar. Biol. 68: 117-133

Larsson, U. (1985). The Baltic Sea. In: Rosenberg, R., Larsson, U., Edler, L. (ed.) Eutrophication in marine waters surrounding Sweden. A review. National Swedish Environmental Protection Board (SNV), Solna. pm 1808, p. 1-140

Larsson, U., Elmgren, R., Wulff, F. (1985). Eutrophication and the Baltic Sea - Causes and consequences. Ambio 14 (1): 9-14.

Larsson, U., Hagström, $\AA$. (1982). Fractionated phytoplankton primary production, exudate release and bacterial production in a Baltic eutrophication gradient. Mar. Biol. 67: $57-70$

Levring, T. (1940). Studien über die Algenvegetation von Blekinge, Südschweden. Dissertātion, Univ, Lund

Levring, T. (1967). Photosynthesis of some marine algae in clear tropical oceanic waters. Botanica mar. 11 (1-4): $72-80$

Lewis, J. R. (1976). Long-term ecological surveillance practical realities in the rocky littoral. Oceanogr. mar. Biol. A. Rev. 14: 371-390

Lindgren, L. (1975). Algal zonation on rocky shores outside Helsinki as basis for pollution monitoring. Merentutkimuslait. Julk./Havsforskningsinst. Skr. 239: 344-347 
Luther, H. (1972). Brackish water production and bioaccumulation problems. IBP i Norden 9: 179-187

Mankowski, W. (1978). The Baltic as an environment able to support life as a source of food. 1: Mankowski, W (ed.) Produktywnosc Ecosystemu Morza Baltyckiego, Polska Akademia Nauk, Wroclaw, Poland: 315-326

Mäkinen, A., Haahtela. I., Ilvessalo, H., Lehto, J. (1984). Changes in littoral rocky shore vegetation in the Seili SW archipelago of Finland. Ophelia Suppl. 3: 157-166

Mathiesen. L. (1974). Notes on the marine algae of Lågskär, Åland Sea. Memo. Soc. Fauna Flora fenn. 41: 71-77

Melvasalo, T., Pawlak, J., Grasshoff, K., Thorell, L., Tsiban, A (ed.) (1981). Assessment of the effects of pollution on the natural resources of the Baltic Sea, 1980. Baltic Sea Environment Proceedings, No. 5B. Baltic Marine Environment Protection commission, Helsinki

Menge, B. A. (1976). Organization of the New England rocky intertidal community: Role of predation, competition and environmental heterogenity. Ecol. Monogr. 46: 355-393

Nehring, D., Schulz, S., Kaiser, W (1984). Long term phosphate and nitrate trends in the Baltic Proper and some biological consequences: A contribution to the discussion concerning the eutrophication of these waters. Rapp. P.-v. Réun. Cons int. Explor. Mer 183: 193-203

Niemistö, L., Tervo, V (1978). Preliminary results of heavy metal contents in some sediment cores in the northern Baltic Sea. Proc. XI Conf. Baltic Oceanogr., Rostock, 24-27 April 1978. 2: 653-672 (Mimeo)

Nyquist, G. (1979). Investigations of some optical properties of seawater with special reference to lignin sulfonates and humic substances. Thesis, Dep. of Anal. and Marine Chem., Chalmers Univ. of Tech. and Univ. of Göteborg

Paine, R. T (1977). Controlled manipulations in the marine intertidal zone, and their contribution to ecological theory. In: Goulden, C. E. (ed.) The changing scenes in natural sciences, 1776-1976, Acad. of Nat. Sci. Spec. Publ. 12, Philadelphia, p. 245-270

Pekkari, S. (1973). Effects of sewage water on benthic vegetation. Oikos Suppl. 15: 185-188

Persson, L. E. (1981). Were macrobenthic changes induced by thinning out of flatfish stocks in the Baltic proper? Ophelia 20: $137-152$

Rönnberg, O. (1984). Recent changes in the distribution of Fucus vesiculosus $\mathrm{L}$, around the Aland islands, N. Baltic, Ophelia, Suppl. 3: 189-193
Smetacek, V., von Bodungen, B., Knoppers, B., Neubert, H., Pollehne, F., Zeitzschel, B. (1980). Shipboard experiments on the effects of vertical mixing on natural plankton populations in the central Baltic Sea. Ophelia Suppl. 1: 77-98

Smith, V H. (1982). The nitrogen and phosphorus dependence of algal biomass in lakes: An empirical and theoretical analysis. Limnol. Oceanogr. 27: 1101-1112

Suess, E., Erlenheuser, H. (1975). History of metal pollution and carbon input in Baltic sediments. Meyniana 27: 63-75

Thurow, F. (1980). The state of fish stocks in the Baltic. Ambio 9: $153-157$

Underwood, A. J., Denley, E. J. (1984). Paradigms, explanations, and generalizations in models for the structure of intertidal communities on rocky shores. In: Strong, D. R. Simberloff, D., Abele, L. G., Thistle, A. B. (ed.) Ecological communities, conceptual issues and the evidence. Princeton University Press, Princeton, p. 151-197

UNEP (1982). The health of the oceans. UNEP Regional Seas Reports and Studies No. 16. UNEP, Geneva

Waern, M. (1952). Rocky shore algae in the Oregrund archipelago. Acta phytogeogr. suec. 30: 1-298

Waern, M. (1965). A vista on the marine vegetation. Acta phytogeogr. suec. 50: 15-28

Wallentinus, I. (1979). Environmental influences on benthic macrovegetation in the Trosa-Askö area, northern Baltic proper. II. The ecology of macroalgae and submersed phanerogams. Contrib. Askö Lab. Univ. Stockholm 25: $1-210$

Wallentinus, I. (1981). Phytobenthos. In: Melvasalo, T., Pawlak, J., Grasshoff, K., Thorell, L., Tsiban, A. (ed.) Assessment of the effects of pollution on the natural resources of the Baltic Sea, 1980. Baltic Sea Environment Proceedings No. 5B. Baltic Marine Environment Protection Commission, Helsinki: 322-342 (+ references)

Wallentinus, I. (1984a). Comparisons of nutrient uptake rates for Baltic macroalgae with different thallus morphologies. Mar. Biol. 80: 215-225

Wallentinus, I. (1984b). Partitioning of nutrient uptake between annual and perennial seaweeds in a Baltic archipelago area. Hydrobiologia 116/117: 363-370

Wallentinus, I., Kautsky, N., Jansson, B.-O. (1985). Competition for nutrients between macroalgal epiphytes and their host plants. (Abstract). Proc. 20th EMBS. Symposium, Hirtshals, Denmark, Sept. 1985 